\title{
Benthic macroinvertebrate tolerance to water acidity in the Grande river sub-basin (San Luis, Argentina)
}

\author{
Susana Tripole ${ }^{1, *}$, E. Adriana Vallania ${ }^{1}$ and María del Carmen Corigliano ${ }^{2}$ \\ ${ }^{1}$ Facultad de Química, Bioquímica y Farmacia. Universidad Nacional de San Luis. Argentina. \\ ${ }^{2}$ Departamento de Ciencias Naturales. Universidad Nacional de Río Cuarto. Argentina. \\ * Corresponding author: stripole@unsl.edu.ar
}

Received: 21/11/06

Accepted: 11/10/07

\begin{abstract}
Benthic macroinvertebrate tolerance to water acidity in the Grande river sub-basin (San Luis, Argentina)

Acidic stress induces multiple adverse effects on the benthic macroinvertebrate community. The methods used to assess the taxa tolerance limit are based on qualitative relations between species at different $\mathrm{pH}$ values. The aim of this work was to estimate the tolerance of benthic macroinvertebrates to water acidification. Four sampling stations were established in the sub-basin of the Grande River, three of them $\left(G_{1}, G_{2}\right.$ and $\left.G_{3}\right)$ on the Grande River and one $(C)$ in one of its tributaries, the Carolina Stream, which receives the acid drainage of an abandoned gold mine. Sample collection $(n=24)$ was carried out with a Surber net and recorded bimonthly between May 1997 and December 1998. The tolerance limit (TL), the optimal pH, the tolerance range (TR) and the acidification index (AI) were calculated for each taxon. $\mathrm{pH}$ values ranged between 3.6 and 9.6. Sixty eight taxa were identified and separated into three groups, according to the TL: $>5.5$ with $50 \%$, an intermediate group with a value of 5.5 and the remaining ones $(40 \%)$ with values $<4.7$. Several acid-sensitive taxa were not present in station C. Dipterans presented higher tolerance to acidity. The application of the acidification index (AI) resulted in category 1 (not acidified) in $\mathrm{G}_{1}, \mathrm{G}_{2}$, and $\mathrm{G}_{3}$ and in category 0.5 (acidity episodes) in $\mathrm{C}$.
\end{abstract}

Key words: $\mathrm{pH}$, tolerance limit, benthic macroinvertebrates, acid stress.

\section{RESUMEN}

Tolerancia de los macroinvertebrados bentónicos a la acidificación del agua en la subcuenca del río Grande (San LuisArgentina)

El estrés ácido induce efectos múltiples perjudiciales para la comunidad de macroinvertebrados bentónicos. Los métodos que valoran el límite de tolerancia de los taxones, se basan en relaciones cualitativas de especies a diferentes $\mathrm{pH}$. El objetivo de este trabajo fue estimar la tolerancia de los macroinvertebrados bentónicos a la acidificación del agua. Se establecieron 4 estaciones de muestreo en la subcuenca del río Grande, tres de ellas $\left(G_{1}, G_{2}\right.$ y $\left.G_{3}\right)$ sobre en río grande y una $(C)$ en uno de sus afluentes, el arroyo Carolina que recibe el drenaje ácido de una mina de oro abandonada. La recolección de las muestras $(\mathrm{n}=24)$ se realizó con red de Surber bimensualmente entre mayo/97 y diciembre/98. Para cada taxón se estimó el límite de tolerancia (LT), el pH optimo, el rango de tolerancia (RT) y el índice de acidificacion (RI). El rango de pH vario entre 3.6-9.6. Se registraron 68 taxones se separaron en tres grupos teniendo en cuenta el LT: $>5.5$ con un $50 \%$, un grupo intermedio con un valor de 5.5 y los restantes $(40 \%)$ con valores < 4.7. Varios taxones ácido sensibles no estuvieron presentes en la estación C. Los dípteros presentaron mayor tolerancia a la acidez. La aplicación de IA resultó categoría 1 (sin acidificar) en $G_{1}, G_{2} y$ $G_{3}$ y con categoría 0.5 (episodios de acidez) en $C$.

Palabras clave: $p H$, límite de tolerancia, macroinvertebrados bentónicos, estrés ácido. 


\section{INTRODUCTION}

Stream acidification, an increasing and wellknown environmental problem, is a consequence of the entrance into the system of substances that surpass the limit of the water buffer capacity, thus producing a decrease in its $\mathrm{pH}$ (Jeffries \& Mills, 1990). One of the causes for this acidification is acid mine drainage (AMD), whose chemical composition depends on the surrounding geology (Aslibekian, 1999). The mixture of these drainages with the natural waters of rivers or streams causes an important impact on the chemistry and biology of these ecosystems since the acidity and the dissolved metals produce significant problems in the water quality, turning it toxic for the aquatic life (Hare, 1992; Herrmann et al., 1993; Vuori, 1995). These effects can continue for many years after the mine activity has ended (Cairns et al., 1971).

Several studies have demonstrated a strong relation between water acidity and the composition of the macroinvertebrate community (Raddum $e t$ al., 1988; Mulholland et al., 1992; Herrmann et al., 1993; Winterbour \& Mc Diffett, 1996; Earle \& Callaghan, 1998; Varner, 2001).

There are differents methods for the assessment of taxa tolerance limits to $\mathrm{pH}$, and they are based on the presence or absence of species at different $\mathrm{pH}$ values (Raddum et al,. 1988). Hämäläinen \& Huttunen (1990) have applied multivariate methods to infer the minimum $\mathrm{pH}$ of a stream from the macroinvertebrate community.

In Argentina there are few antecedents about this problem. There is a study on the Quebrada Minas River (Andalgalá River basin, Catamarca province) which has shown a $\mathrm{pH}$ of 3 due to a mine acid drainage (González \& Lavilla, 1999), where Chironomidae were found almost exclusively (Grosso et al., 1999). In the Carolina stream (Quinto River basin, San Luis province) Tripole et al. (2006) have found changes in the macroinvertebrate community, such as a decrease in its abundance and richness, and a replacement by more tolerant species.

The purpose of this study was to determine the tolerance of benthic macroinvertebrates to water acidification in the Grande River sub-basin (San Luis-Argentina).

\section{MATERIALS AND METHODS}

The study was carried out in the Grande River sub-basin, which starts at $2.160 \mathrm{~m}$ a.s.l. near La Carolina village and flows south $30.6 \mathrm{~km}$ to the Quinto River at $1.070 \mathrm{~m}$ a.s.l. The Grande River is a $6^{\text {th }}$ order river whose basin includes $291.3 \mathrm{~km}^{2}$. One of the river tributaries, the $\mathrm{Ca}$ rolina stream, receives the acid drainage of an ancient gold mine abandoned during the first decades of the $20^{\text {th }}$ century. In this region, rains mostly occur from October to March.

Four sampling sites were established for the study (Fig. 1), three of them in the Grande River $\left(G_{1}, G_{2}\right.$ and $\left.G_{3}\right)$ and the other in the Carolina stream (C), which is located downstream from the acid drainage. The $\mathrm{G}_{1}$ site is located upstream the river confluence with the Carolina stream whereas the other two are located downstream from it. The samplings were carried out bimonthly from May 1997 to March 1998.

The sampling stations selected were similar, especially in the substrate type with predominance of grave and sand, and with scarce aquatic and riverside vegetation.

To estimate the hydraulic parameters of the riverbed, two transversal transects were done to measure width and depth every $30 \mathrm{~cm}$. Surface current velocity was measured using a floater three times every $5 \mathrm{~m}$ and averaging the measures. Flows were calculated using mean data for depth, width and, current velocity. Temperature (accuracy $\pm 0.5^{\circ} \mathrm{C}$ ), conductivity (accuracy $\pm 1 \%$ ), and $\mathrm{pH}$ (accuracy $\pm 0.01 \mathrm{pH}$ ) were measured in situ using CONSORT C532 portable sensors. Water samples for the chemical analyses were collected in polythene bottles and transported to the lab where alkalinity was determined using a potentiometric titration method (ORION 940-960) and sulphuric acid as reagent titre. Hardness was determined using an EDTA titration and Eriochrome black $\mathrm{T}$ as an indicator.

The design for field sampling was stratified 


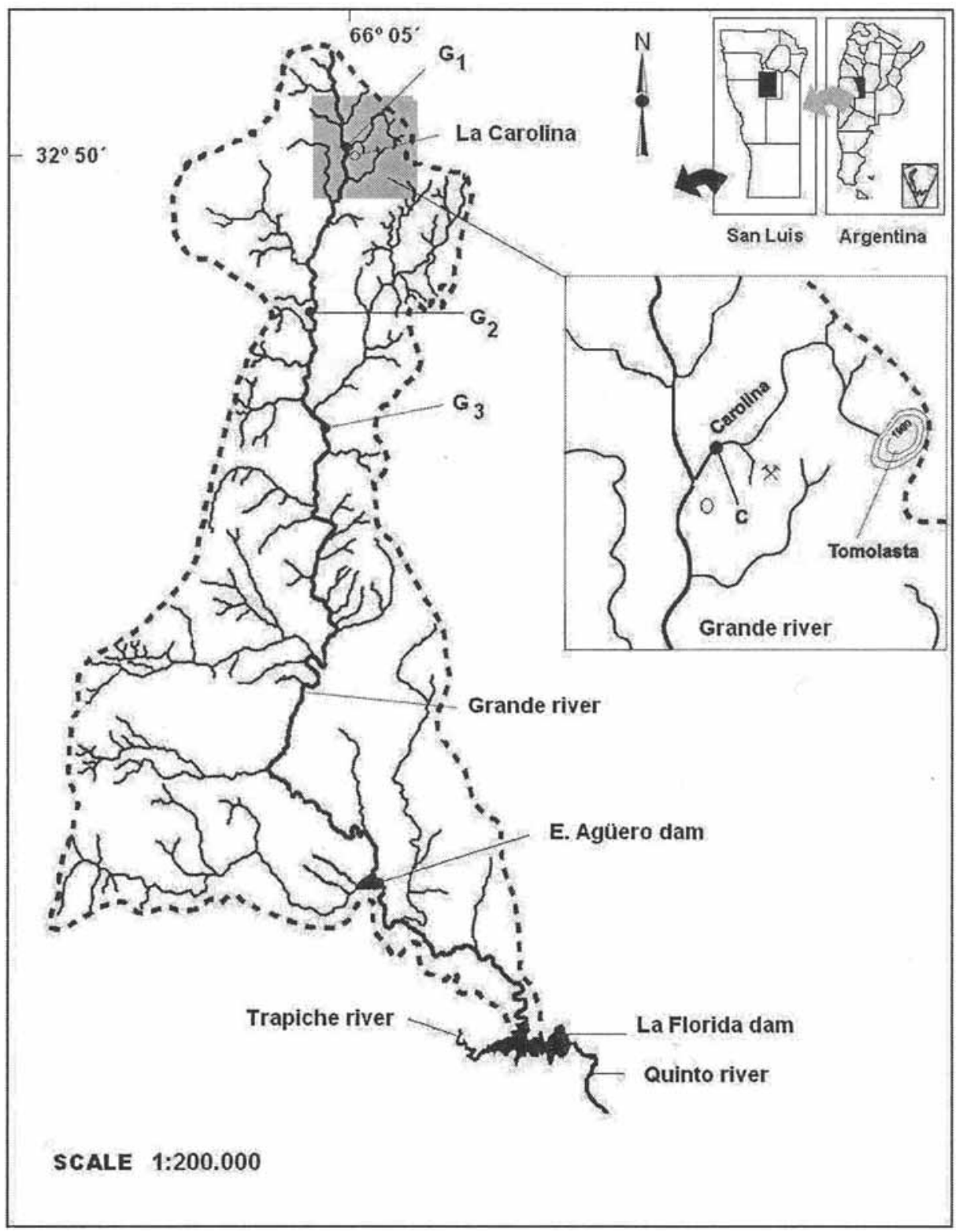

Figure 1. Sampling sites established in the Grande River $\mathrm{G}_{1}, \mathrm{G}_{2}$ and $\mathrm{G}_{3}$, and the Carolina stream $\mathrm{C}$ before and after the acid drainage of an abandoned gold mine. Sitios de muestreo sobre el río de Grande $G_{1}, G_{2}$ y $G_{3}$ y el arroyo Carolina C antes y después del drenaje ácido de una mina de oro abandonada.

at random. Samples of benthic macroinvertebrates were obtained using Surber samplers (with an area of $0.09 \mathrm{~m}^{2}$ and $300 \mu \mathrm{m}$ net mesh size). Three pseudo-replicates were taken from each station (72 samples in all) and averaged for the analysis. The material was fixed in situ and preserved in alcohol (70\%). The organisms were isolated under the microscope, and the counts were carried out considering the complete sample. The organisms identification was done up to family and/or genus or species level since the taxonomic definition level would not significantly affect the final results.

The mean values, standard deviation, and 
Table 1. Number of taxa and percentage of contribution of the insects in relation to non-insects in the sites studied in the sub-basin in the Grande River (San Luis). Número de taxones y porcentaje de contribución de los insectos con respecto a los no insectos en los sitios estudiados de la subcuenca del río Grande.

\begin{tabular}{lcccc}
\hline & $\mathbf{G}_{1}$ & $\mathbf{G}_{2}$ & $\mathbf{G}_{3}$ & $\mathbf{C}$ \\
& $\mathrm{pH}=6.8-9.5$ & $\mathrm{pH}=6.7-8.6$ & $\mathrm{pH}=6.8-8.5$ & $\mathrm{pH}=3.6-5.5$ \\
\hline Hydroidea & 1 & 1 & 1 & 1 \\
Tricladida & 1 & 1 & 1 & \\
Basommatophora & 2 & 2 & 2 & 6 \\
Oligochaeta & 9 & 9 & 7 & \\
Amphipoda & 1 & & 1 & 2 \\
Ephemeroptera & 5 & 6 & 6 & 2 \\
Odonata & 3 & 1 & 3 & 1 \\
Heteroptera & 5 & 7 & 2 & \\
Trichoptera & 9 & 1 & 5 & 9 \\
Lepidoptera & 1 & 7 & 8 & 12 \\
Coleoptera & 11 & 9 & 8 & 79 \\
Diptera & 10 & 73 & 73 & \\
\% of insects & 76 & & & \\
\hline
\end{tabular}

value ranges were calculated for the different variables of each station. Each station's $\mathrm{pH}$ was correlated with the flow.

According to Hämäläinen \& Huttnen (1990), the tolerance limit (TL) is defined as the lowest $\mathrm{pH}$ value at which the taxon is found; the optimal $\mathrm{pH}$ was defined as the $\mathrm{pH}$ mean value and the tolerance range (TR) as the standard deviation. The $\mathrm{TL}$, the optimal $\mathrm{pH}$, and the $\mathrm{TR}$ were estimated for each taxon.

The acidification index (AI) proposed by Raddum et al. (1988) to infer the river acidification state considering the observed organisms was calculated. This index uses a hierarchical system, which attributes a category to the species according to their acidity tolerance. Considering the TL, the organisms were ordered in four categories: category 1 (environment without acidification) at a $\mathrm{pH}$ higher than 5.5; category 0.5 (with acidity episodes) with a $\mathrm{pH}$ between 5.5 and 5; category 0.25 (marked acidity) with $\mathrm{pH}$ values between 5 and 4.7, and category 0 (highly acidified) with a $\mathrm{pH}$ lower than 4.7. To infer the condition of each site, an acidification number was assigned taking into account the presence of organisms with a higher tolerance limit as an indicator of higher $\mathrm{pH}$.

The relative abundance of insects in relation to non-insects was calculated considering the total benthic taxa (Table 1).

\section{RESULTS}

The characterization of each sample station with the geographical features and hydrological, physical and chemical variables is shown in Table 2.

The mine acid drainage produced a decrease in the $\mathrm{pH}$ values and in the total alkalinity below the detection limit $(<0.1 \mathrm{mg} / \mathrm{L}$ of $\left.\mathrm{CaCO}_{3}\right)$ in the studied stream section. Total hardness increased by an average of $173.5 \pm$ $65.2 \mathrm{mg} / \mathrm{L}$ of $\mathrm{CO}_{3} \mathrm{Ca}$ as a result of the mineral erosion. An increase in the ionic concentration, reflected in the specific conductivity values whose average increased in relation to the other stations, was also observed (Table 2).

The comparison of $\mathrm{pH}$ mean values showed significant differences between the reference stations and station $\mathrm{C}$ with a marked decrease in the latter (Fig. 2 and Table 2).

The estimated values of TL, AI, optimal $\mathrm{pH}$, and $\mathrm{pH}$ range can be observed in Table 3. Sixtyeight taxa were identified and were separated in three groups keeping in mind the TL: $>5.5$ with $50 \%$, an intermediate group with a value of 5.5 and the remaining ones $(40 \%)$ with values $<4.7$. The acid-sensitive taxa absent in station $\mathrm{C}$ were: turbellaria, gastropods, crustaceans, lepidoptera, trichoptera (except for Metrichia neotropicalis) and ephemeroptera (except for Caenis sp.) (Table 3). Dipterans exhibited higher tolerance to acidi- 
Table 2. Geographical parameters and mean values, standard deviation, and range of the physical and chemical variables of the sites studied in the sub-basin in the Grande River (San Luis). Parámetros geográficos y valores medios, desviación estándar y rango de las variables físicas y químicas de los sitios estudiados en la subcuenca del río Grande (San Luis).

\begin{tabular}{|c|c|c|c|c|}
\hline & $\mathrm{G}_{1}$ & $\mathrm{G}_{2}$ & $\mathrm{G}_{3}$ & $\mathrm{C}$ \\
\hline Elevation (m s.n.m.) & 1660 & 1600 & 1560 & 1690 \\
\hline Longitude $(\mathrm{km})$ & 2.35 & 6.72 & 9.77 & 2.50 \\
\hline Stream Order & $2^{\circ}$ & $3^{\circ}$ & $4^{\circ}$ & $2^{\circ}$ \\
\hline Wide (m) & $\begin{array}{c}5.45 \pm 0.48 \\
(4.7-6.0)\end{array}$ & $\begin{array}{c}9.51 \pm 2.09 \\
(5.4-11)\end{array}$ & $\begin{array}{c}10.06 \pm 3.11 \\
(5.8-15.5)\end{array}$ & $\begin{array}{c}3.27 \pm 0.22 \\
(3-3.6)\end{array}$ \\
\hline Depth (m) & $\begin{array}{c}0.21 \pm 0.07 \\
(0.13-0.3)\end{array}$ & $\begin{array}{c}0.07 \pm 0.04 \\
(0.03-0.14)\end{array}$ & $\begin{array}{c}0.15 \pm 0.03 \\
(0.12-0.19)\end{array}$ & $\begin{array}{c}0.18 \pm 0.03 \\
(0.14-0.21)\end{array}$ \\
\hline Velocity (m/seg) & $\begin{array}{c}0.06 \pm 0.03 \\
(0.005-0.1)\end{array}$ & $\begin{array}{l}0.41 \pm 0.15 \\
(0.18-0.64)\end{array}$ & $\begin{array}{c}0.29 \pm 0.19 \\
(0.05-0.53)\end{array}$ & $\begin{array}{c}0.03 \pm 0.004 \\
(0.02-0.03)\end{array}$ \\
\hline Discharge $\left(\mathrm{m}^{3} / \mathrm{seg}\right)$ & $\begin{array}{c}0.07 \pm 0.04 \\
(0.02-0.14)\end{array}$ & $\begin{array}{l}0.29 \pm 0.17 \\
(0.08-0.52)\end{array}$ & $\begin{array}{c}0.51 \pm 0.39 \\
(0.4-1.01)\end{array}$ & $\begin{array}{c}0.017 \pm 0.004 \\
(0.01-0.023)\end{array}$ \\
\hline Water Temperature $\left({ }^{\circ} \mathrm{C}\right)$ & $\begin{array}{c}15 \pm 4.7 \\
(7-19)\end{array}$ & $\begin{array}{c}15.8 \pm 3.2 \\
(12-20)\end{array}$ & $\begin{array}{c}16.0 \pm 3.8 \\
(11-22)\end{array}$ & $\begin{array}{c}16.6 \pm 4.3 \\
(10.5-22)\end{array}$ \\
\hline $\mathbf{p H}$ & $\begin{array}{l}8.1 \pm 1.1 \\
(6.8-9.5)\end{array}$ & $\begin{array}{l}7.6 \pm 0.8 \\
(6.7-8.6)\end{array}$ & $\begin{array}{l}7.5 \pm 0.6 \\
(6.8-8.5)\end{array}$ & $\begin{array}{l}4.5 \pm 0.8 \\
(3.6-5.5)\end{array}$ \\
\hline Conductivity $(\mu \mathrm{S} / \mathrm{cm})$ & $\begin{array}{c}166.4 \pm 19.2 \\
(144-185)\end{array}$ & $\begin{array}{c}175.3 \pm 21.2 \\
(152-196)\end{array}$ & $\begin{array}{c}209.8 \pm 17.1 \\
(190-239)\end{array}$ & $\begin{array}{c}449.8 \pm 193.2 \\
(239-700)\end{array}$ \\
\hline Alkalinity $\left(\mathrm{mg} / \mathrm{L} \mathrm{CO}_{3} \mathrm{Ca}\right)$ & $\begin{array}{c}85.6 \pm 7.2 \\
(72-92)\end{array}$ & $\begin{array}{c}81.8 \pm 27.7 \\
(26-99)\end{array}$ & $\begin{array}{c}132.2 \pm 6.3 \\
(121-139)\end{array}$ & 0 \\
\hline Total Hardness $\left(\mathrm{mg} / \mathrm{L} \mathrm{CO}_{3} \mathrm{Ca}\right)$ & $\begin{array}{c}77.5 \pm 5.4 \\
(70-85)\end{array}$ & $\begin{array}{c}90.6 \pm 18.4 \\
(80-128)\end{array}$ & $\begin{array}{c}104.8 \pm 7.9 \\
(90-111)\end{array}$ & $\begin{array}{c}173.5 \pm 65.2 \\
(108-263)\end{array}$ \\
\hline
\end{tabular}

ty except for Stratiomidae and Simuliidae.

The correlations between the reference stations' $\mathrm{pH}$ and flows were not significant, independently from the season and the rains $\left(\mathrm{G}_{1}: \mathrm{R}^{2}=2.34, p=0.80 ; \mathrm{G}_{2}: \mathrm{R}^{2}=14.45, p=0.46\right.$ and $\mathrm{G}_{3}: \mathrm{R}^{2}=4.91, p=0.67$ ), whereas in station $\mathrm{C}$, with a pH lower than 5.5, the correlation was significant in relation to the low water period in winter $\left(\mathrm{R}^{2}=68.5, p=0.042\right)$.

The application of the acid number yielded 34 taxa with $A I=1$, present in $G_{1}, G_{2}$ and $G_{3}$ and corresponding to category 1 (not acidified), and 7 taxa with $\mathrm{AI}=0.5$, present in $\mathrm{C}$ corresponding to category 0.5 (acidity episodes) (Table 3 ).

A decrease in aquatic insects was observed in station C. However, there was an increase in their

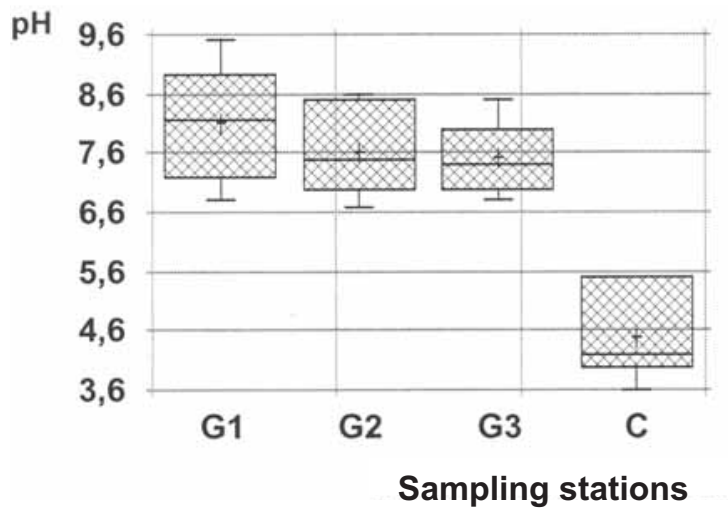

Figure 2. Comparison of $\mathrm{pH}$ among the sampling stations (Analysis of the variance and Turkey's test). Comparación de pH entre las estaciones de muestreo (Análisis de la varianza y test de Tukey). 
Table 3. Raddum acidification index (AI) estimated values (Raddum et al. 1988), the tolerance limit (TL), optimum pH, and range of tolerance observed in the taxa registered in the studied stations. Valores estimados del indice de acidificación (IA) de Raddum et al. (1988), límite de tolerancia (TL), el pH óptimo y el rango de tolerancia observados en los taxones registrados en las staciones estudiadas.

\begin{tabular}{|c|c|c|c|c|c|c|c|c|c|}
\hline \multirow{2}{*}{$\begin{array}{l}\text { Order } \\
\text { Hydroidea }\end{array}$} & \multirow{2}{*}{$\begin{array}{l}\text { Taxa } \\
H y d r a \mathrm{sp} .\end{array}$} & \multirow{2}{*}{$\begin{array}{l}\mathbf{A I} \\
0.5\end{array}$} & \multirow{2}{*}{$\begin{array}{l}\text { TL } \\
5.5\end{array}$} & \multirow{2}{*}{$\begin{array}{l}\text { Range } \\
5.5-9.5\end{array}$} & \multirow{2}{*}{$\begin{array}{c}\text { Optimal pH } \\
7.8\end{array}$} & \multicolumn{4}{|c|}{ Studied station } \\
\hline & & & & & & G1 & $\mathrm{G} 2$ & G3 & $\overline{\mathrm{C}}$ \\
\hline Tricladida & Girardia sp. & 1 & 6.8 & $6.8-9.5$ & 8.1 & G1 & $\mathrm{G} 2$ & G3 & \\
\hline \multirow[t]{2}{*}{ Basommatophora } & Biomphalaria sp. & 1 & 6.7 & $6.7-9.5$ & 7.9 & G1 & $\mathrm{G} 2$ & G3 & \\
\hline & Stenophysa sp. & 1 & 6.7 & $6.7-8.6$ & 8.2 & G1 & $\mathrm{G} 2$ & G3 & \\
\hline \multirow[t]{8}{*}{ Tubificida } & Nais communis & 0.5 & 5.5 & $5.5-9.5$ & 7.5 & G1 & $\mathrm{G} 2$ & G3 & $\mathrm{C}$ \\
\hline & Nais variabilis & 1 & 8.0 & $8-8.8$ & 8.4 & G1 & & G3 & \\
\hline & Nais elinguis & 1 & 6.7 & $6.7-8.9$ & 7.9 & G1 & $\mathrm{G} 2$ & & \\
\hline & Chaetogaster sp. & 0.5 & 5.5 & $5.5-9.5$ & 7.5 & G1 & $\mathrm{G} 2$ & G3 & $\mathrm{C}$ \\
\hline & Pristinella sp. & 1 & 6.7 & $6.7-8.9$ & 7.7 & G1 & $\mathrm{G} 2$ & G3 & \\
\hline & Pristina sp. & 0 & 4.1 & $4.1-8.9$ & 7.1 & G1 & $\mathrm{G} 2$ & G3 & $\mathrm{C}$ \\
\hline & Tubificidae & 0 & 3.6 & $3.6-8.6$ & 6.9 & G1 & $\mathrm{G} 2$ & G3 & $\mathrm{C}$ \\
\hline & Enchytraeidae & 0 & 4.3 & $4.3-9.5$ & 6.6 & G1 & $\mathrm{G} 2$ & G3 & $\mathrm{C}$ \\
\hline Megadrila & Megadrili & 0.5 & 5.5 & $5.5-8.6$ & 7.3 & & $\mathrm{G} 2$ & & $\mathrm{C}$ \\
\hline Aphanoneura & Aelosoma & 1 & 7.0 & $7-8.5$ & 7.6 & G1 & $\mathrm{G} 2$ & & \\
\hline Amphipoda & Hyalella sp. & 1 & 6.8 & $6.8-9.5$ & 7.7 & G1 & & G3 & \\
\hline \multirow[t]{6}{*}{ Ephemeroptera } & T. popayanicus & 1 & 6.7 & $6.7-9.5$ & 6.6 & G1 & $\mathrm{G} 2$ & G3 & \\
\hline & Leptohyphes sp. & 1 & 6.8 & $6.8-8.9$ & 6.4 & G1 & $\mathrm{G} 2$ & G3 & \\
\hline & Caenis sp. & 0 & 4.0 & $4-9.5$ & 6.1 & G1 & $\mathrm{G} 2$ & G3 & $\mathrm{C}$ \\
\hline & Baetodes sp. & 1 & 7.5 & $7.5-8.5$ & 7.8 & & $\mathrm{G} 2$ & G3 & \\
\hline & Camelobaetidius penai & 1 & 6.8 & $6.8-8.9$ & 7.5 & G1 & $\mathrm{G} 2$ & G3 & \\
\hline & Baetidae & 1 & 6.7 & $6.7-9.5$ & 6.7 & G1 & $\mathrm{G} 2$ & G3 & \\
\hline \multirow[t]{4}{*}{ Odonata } & Progomphus sp. & 0 & 4.0 & $4-8.6$ & 6.5 & & $\mathrm{G} 2$ & G3 & $\mathrm{C}$ \\
\hline & Aeshna sp. & 1 & 6.7 & $6.7-8.9$ & 7.6 & G1 & $\mathrm{G} 2$ & G3 & \\
\hline & Limnetron sp. & 1 & 6.7 & $6.7-9.5$ & 8.0 & G1 & $\mathrm{G} 2$ & & \\
\hline & Argia sp. & 0 & 4 & $4-9.5$ & 7.8 & G1 & $\mathrm{G} 2$ & G3 & $\mathrm{C}$ \\
\hline \multirow[t]{5}{*}{ Heteroptera } & Sigara sp. & 0 & 3.6 & $3.6-9.5$ & 6.6 & G1 & & G3 & $\mathrm{C}$ \\
\hline & Ectemnostega sp. & 1 & 6.8 & $6.8-8.9$ & 7.6 & G1 & & & \\
\hline & Lethocerus sp. & 1 & 6.8 & 6.8 & 6.8 & G1 & & & \\
\hline & Ambrysus sp. & 0 & 4.0 & $4-8.9$ & 7.3 & G1 & $\mathrm{G} 2$ & G3 & $\mathrm{C}$ \\
\hline & Notonectidae & 1 & 7.5 & 7.5 & 7.5 & G1 & & & \\
\hline \multirow[t]{9}{*}{ Trichoptera } & Metrichia neotropicalis & 0.5 & 5.5 & $5.5-9.5$ & 7.5 & G1 & $\mathrm{G} 2$ & G3 & $\mathrm{C}$ \\
\hline & Hydroptila sp. & 1 & 6.7 & $6.7-8.9$ & 6.1 & G1 & $\mathrm{G} 2$ & G3 & \\
\hline & Oxyethira sp. & 1 & 7.5 & $7.5-8.9$ & 8.3 & G1 & $\mathrm{G} 2$ & G3 & \\
\hline & Marilia cinerea & 1 & 6.8 & $6.8-8.9$ & 6.8 & G1 & & G3 & \\
\hline & Helicopsyche sp. & 1 & 6.7 & $6.7-9.5$ & 6.6 & G1 & $\mathrm{G} 2$ & G3 & \\
\hline & P. joergenseni & 1 & 6.8 & $6.8-9.5$ & 8.1 & G1 & $\mathrm{G} 2$ & & \\
\hline & Chimarra sp. & 1 & 6.7 & $6.7-9.5$ & 8.1 & G1 & $\mathrm{G} 2$ & & \\
\hline & Smicridia spp. & 1 & 6.8 & $6.8-8.8$ & 7.9 & G1 & $\mathrm{G} 2$ & & \\
\hline & Protoptyla dubitans & 1 & 9.5 & 9.5 & 9.5 & G1 & & & \\
\hline Lepidoptera & Pyralidae & 1 & 6.7 & $6.7-8.9$ & 7.8 & G1 & $\mathrm{G} 2$ & G3 & \\
\hline \multirow[t]{8}{*}{ Coleoptera } & Dytiscidae (larvas) & 1 & 6.8 & $6.8-9.5$ & 8.1 & G1 & & & \\
\hline & Liodessus sp. & 0 & 3.6 & $3.6-9.5$ & 6.7 & G1 & $\mathrm{G} 2$ & G3 & $\mathrm{C}$ \\
\hline & Hydroporinae & 0 & 3.6 & $3.6-8$ & 6.2 & & & G3 & $\mathrm{C}$ \\
\hline & Lancetes sp. & 0 & 4.0 & $4-9.5$ & 6.9 & G1 & $\mathrm{G} 2$ & G3 & $\mathrm{C}$ \\
\hline & Elmidae (larvas) & 0 & 3.6 & $3.6-9.5$ & 7.3 & G1 & $\mathrm{G} 2$ & G3 & $\mathrm{C}$ \\
\hline & Cylloepus sp. & 0 & 4.0 & $4-8.6$ & 7.3 & G1 & $\mathrm{G} 2$ & G3 & $\mathrm{C}$ \\
\hline & Austrolimnius sp. & 1 & 6.7 & $6.7-8.6$ & 7.6 & G1 & $\mathrm{G} 2$ & G3 & \\
\hline & Hidrophilidae & 0 & 4.0 & $4-9.5$ & 6.3 & G1 & & & $\mathrm{C}$ \\
\hline
\end{tabular}


Table 3. Cont.

\begin{tabular}{|c|c|c|c|c|c|c|c|c|c|}
\hline Order & Taxa & $\mathbf{A I}$ & TL & Range & Optimal pH & \multicolumn{4}{|c|}{ Studied station } \\
\hline & Berosus spp. & 0 & 4.0 & $4-9.5$ & 6.9 & G1 & & & $\bar{C}$ \\
\hline & Hemiosus spp. & 1 & 6.8 & $6.8-8.5$ & 7.6 & G1 & $\mathrm{G} 2$ & G3 & \\
\hline & Staphylinidae & 0 & 4.0 & $4-8.8$ & 7.1 & G1 & $\mathrm{G} 2$ & G3 & $\mathrm{C}$ \\
\hline & Gyrinus (O.) argentinus & 0.5 & 5.5 & $5.5-9.5$ & 7.6 & G1 & & & $\mathrm{C}$ \\
\hline & Helichus cordubensis & 1 & 6.7 & $6.7-8.6$ & 7.9 & & $\mathrm{G} 2$ & & \\
\hline \multirow[t]{15}{*}{ Diptera } & Chironominae & 0 & 3.6 & $3.6-9.5$ & 6.9 & G1 & $\mathrm{G} 2$ & G3 & $\mathrm{C}$ \\
\hline & Orthocladinae & 0 & 3.6 & $3.6-9.5$ & 6.9 & G1 & $\mathrm{G} 2$ & G3 & $\mathrm{C}$ \\
\hline & Tanypodinae & 0 & 4.0 & $4-9.5$ & 7.2 & G1 & $\mathrm{G} 2$ & G3 & $\mathrm{C}$ \\
\hline & Tipulidae & 0 & 4.0 & $4-9.5$ & 7.2 & G1 & $\mathrm{G} 2$ & G3 & $\mathrm{C}$ \\
\hline & Stratiomidae & 1 & 6.8 & $6.8-8.5$ & 7.6 & G1 & $\mathrm{G} 2$ & & \\
\hline & Dolichopodidae & 0 & 4.1 & 4.1 & 4.1 & & & & $\mathrm{C}$ \\
\hline & Muscidae & 0 & 3.6 & $3.6-8.9$ & 6.7 & G1 & $\mathrm{G} 2$ & G3 & $\mathrm{C}$ \\
\hline & Psychodidae & 0 & 4.0 & $4-8$ & 5.7 & G1 & & G3 & $\mathrm{C}$ \\
\hline & Ceratopogonidae & 0 & 3.6 & $3.6-9.5$ & 6.9 & G1 & $\mathrm{G} 2$ & G3 & $\mathrm{C}$ \\
\hline & Forciypominae & 0.5 & 5.5 & 5.5 & 5.5 & & & & $\mathrm{C}$ \\
\hline & Ephydridae & 0 & 3.6 & $3.6-8.5$ & 5.8 & G1 & & G3 & $\mathrm{C}$ \\
\hline & Empididae & 0 & 4.0 & $4-9.5$ & 6.1 & G1 & $\mathrm{G} 2$ & & $\mathrm{C}$ \\
\hline & Culicidae & 0 & 4.1 & $4.1-5.5$ & 5.1 & & & & $\mathrm{C}$ \\
\hline & Simulium lahilei & 1 & 7.5 & $7.5-8.5$ & 8.0 & & $\mathrm{G} 2$ & & \\
\hline & Simulium wolffueguelli & 1 & 7.0 & $7-9.5$ & 8.1 & G1 & $\mathrm{G} 2$ & G3 & \\
\hline
\end{tabular}

relative abundance since some taxa of non-insects diminished when the $\mathrm{pH}$ decreased (Table 3 ).

\section{DISCUSSION}

The sub-basin $\mathrm{pH}$ values ranged between 3.6 and 9.6. The stations with a $\mathrm{pH}$ lower than 5.5 showed exclusion of macroinvertebrates.

Although taxonomic identification is difficult to carry out and the local fauna does not fit into the taxonomic lists proposed by Hämäläinen \& Huttunen (1990), thus making the comparisons difficult, the TLs determined in this study are similar to those found by these authors when comparing the highest taxonomic levels.

Besides, even though the insects exhibit a global reduction in acid biotopes, their relative abundance may be increased since some noninsect taxa diminished when the $\mathrm{pH}$ decreased (Ward, 1992). This situation is similar to that observed in the studied sub-basin with the disappearance of gastropods, crustaceans and three taxa of oligochaeta.

In general terms, the biological association observed in this stream section was comparable to that found in other streams acidified by AMD, where the presence of Chironomidae, Dytiscidae, and Corixidae was observed together with the disappearance or decrease of Ephemeroptera, Plecoptera, and Thrichoptera (EPT) (Earle \& Callaghan, 1998; Last, 2001; Varner, 2001).

Ephemeroptera and Trichoptera are strongly affected by a decrease in $\mathrm{pH}$, and they are generally used for monitoring acidified environments (Raddum et al., 1989; Hämäläinen \& Huttunen, 1990; Mulholland et al., 1992; Fjellheim \& Raddum, 1995; Barbour et al., 1997; Varner, 2001). Few Ephemeroptera are tolerant to AMD, and some families have been observed in the northern hemisphere at $\mathrm{pHs}$ higher than 4.9 (Rosemond et al., 1992; Last, 2001). In this study, Caenidae (Caenis sp.) were found at $\mathrm{pH}=4$ and the rest at a TL higher than 6.7. Roback \& Richardson (1969) have observed the disappearance of Odonata, Ephemeroptera, and Plecoptera in constant AMD conditions, whereas the effect is smaller under intermittent conditions. Although the Carolina stream is not under intermittent conditions, it exhibits seasonality with a period of low waters in winter. During this period, although there is a $\mathrm{pH}$ decrease, the presence of some Odonata such as Progomphus sp. and Argia sp. was observed at $\mathrm{pH}=4$. 
Species that depend on the calcium ion for the formation of their shells, such as mollusks and crustaceans, are sensitive to acidification (Appelberg et al., 1993; Herrmann et al., 1993) and are restricted to $\mathrm{pHs}$ higher than 5.5 since the calcium ions dissolved in water are insufficient in relation to protons (Allan, 1995). However, these groups are infrequent, but abundant when present, in the streams in the province of San Luis (Medina et al., 1997; Vallania et al., 2002).

The acidity increase in the water column and the discharge of metals caused by the AMD are usually followed by the deposition on the substrate of sediments contaminated by metals (Last, 2001). Oligochaeta are organisms strongly associated with a sediment that possesses great buffer capacity, thus making them more tolerant to acidity since they are not affected by the water $\mathrm{pH}$ (Mulholland et al., 1992). In this study a slight decrease of these organisms was observed.

In relation to Coleopterans, Liodessus sp., from the Dytiscidae family, which is the most frequently cited as an acid stress tolerant, was in high abundance (Earle \& Callaghan, 1998; Winterbourn \& Mc Diffett, 1996).

Chironomidae larvae, which comprised most of the dominant fauna, have been cited as the most tolerant to acid stress by various authors (Zullo \& Stahl, 1987; Appelberg et al., 1993; Tank \& Winterbourn, 1995), especially due to AMD (Winterbourn \& Mc Diffett; 1996; Varner, 2001). In the Carolina stream, they were found with a TL of 3.6 and with a wide $\mathrm{pH}$ range. Experimental studies by Rousch et al. (1997) have shown that Chironomidae larvae are tolerant to acid conditions and are affected at $\mathrm{pHs}$ lower than 4 .

It can be considered that the TL and the acidification number are good indicators of the water biological quality (Raddum et al., 1988; Hämäläinen \& Huttunen, 1990).

The behaviour and physiology of the benthic organisms are quite varied, and generalizations seem to be difficult to make. It is not possible to have an absolute TL for each species due to the natural differences in the populations' sensitivity, food availability, and other factors that can modify the effect of $\mathrm{pH}$ on the presence/absence of species in acidified rivers (Hämäläinen \& Hut- tunen, 1990). Some species were not observed at a determined $\mathrm{pH}$, whereas they were present in another sample with the same value, which might indicate that there are other factors, besides $\mathrm{pH}$, that can modify the community.

The tolerance limit and the prediction method, based on species categorization according to $\mathrm{pH}$, allowed for the estimation of the $\mathrm{pH}$ of the studied section. Therefore, the resulting category was 0.5 (acidity episodes) although most of the species were found at a $\mathrm{pH}$ lower than 4.7 (Raddum et al., 1988). This result is comparable to that obtained by multimetric indices (Tripole \& Corigliano, 2005), through which the environment resulted to be a moderately deteriorated one.

The macroinvertebrate community present in a particular region is an indicator of the environmental conditions. The biological evaluations of these macroinvertebrates offer crucial information about stream health, which cannot be obtained through water chemistry alone.

\section{ACKNOWLEDGMENT}

The present study was financed by the Secretaria de Ciencia y Técnica from the Universidad Nacional de San Luis. Argentina.

\section{REFERENCES}

ALLAN, J. D. 1995. Stream water chemistry. In: Stream Ecology structure and function of running waters. Chapmman \& Hall (eds.): 23-43. Boundary Row, London, UK.

APPELBERG, M., BI HENRIKSON, L. HENRIKSON \& M. SVEDÄNG. 1993. Biotic Interactions within the Littoral Community of Swedish Forest Lakes During Acidification. Ambio, XXII(5): 290296.

ASLIBEKIAN, O., N. GRAY \& R. MOLES. 1999. Metal Contamination of surface water related to past mining activity in Ireland. Mine, Water \& Environment. IMWA Congress. 13-17 September 1999. Sevilla, España: 535-541.

BARBOUR, M. T., J. GERRITSEN, B. D. SNYDER \& J. B. STRIBLING. 1997. Revision to Rapid Bioassessment Protocols for Use in Streams and 
Rivers. EPA 841-D-97-002. Washington, D.C.

CAIRNS, J., J. S. CROSSMAN, K. L. DICKSON \& E. E. HERRICKS. 1971. The recovery of damaged streams. ASB Bulletin, 18: 79-106.

EARLE, J. \& T. CALLAGHAN. 1998. Impacts of mine drainage on aquatic life, water uses, and manmade structures. In: Coal Mine Drainage Prediction and Pollution Prevention in Pennsylvania. K. Brady, W. Smith, and J. Schueck (eds.): 1-10 Pennsylvania Department of Environmental Protection.

FJELLHEIM, A. \& RADDUM, G. G. 1995. Benthic animal response after liming of three south Norwegian rivers. Water Air and Soil Pollution, 85: 931-936.

GONZÁLEZ, J. A. y E. O. LAVILLA. 1999. Agua: Caracterización físico-química de las aguas superficiales de la cuenca del río Andalgalá. In: Biodiversidad de Agua Rica (Catamarca, Argentina). E. Lavilla y J. González (eds.): 75-134. BHP COPPER y Fundación Miguel Lillo, Argentina.

GROSSO, L. E., M. PERALTA y F. ROMERO. 1999. Invertebrados acuáticos de los ríos Choya, Potrero, Quebrada Minas, Candado, Blanco y Andalgalá. In: Biodiversidad de Agua Rica (Catamarca, Argentina). E. Lavilla y J. González (eds).: 135-146. BHP COPPER y Fundación Miguel Lillo, Argentina.

HÄMÄLÄINEN, H. \& P. HUTTUNEN. 1990. Estimation of Acidity in Streams by Means of Benthic Invertebrates: Evaluation of Two Methods. In: Acidification in Finland. P, Kauppi, P, Anttilla \& K. Kenttämies (eds.): 1051-1070. Springer Verlag, Berlin Heidelberg.

HARE, L. 1992. Aquatic Insects and Trace Metals: Bioavailability, Bioaccumulation y Toxicity. Critical Reviews in Toxicology, 22(5/6): 327-369.

HERRMANN, J., E. DEGERMAN, A. GERHARDT, C. JOHANSSON, P. LINGDELL \& I. MUNIZ. 1993. Acid-stress effects on stream biology. Ambio, XXII(5): 298-307.

HYNES, H. B. 1960. The Biology of Polluted Waters. Liverpool University Press, Liverpool. 202 pp.

JEFFRIES, M. \& D. MILLS. 1990. Acidification of fresh waters. In: Freshwater Ecology Principles and Applications. Belhaven Press (eds.): 157-172. London and NY.

LAST, J. 2001. Impact of specific acid mine drainage contaminants on macroinvertebrate communities in southeastern Ohio streams. Thesis Master of Science, Collage of Art and Sciences of Ohio University. $97 \mathrm{pp}$.
MEDINA, A. I., E. A. VALLANIA, E. S. TRIPOLE y P. A. GARELIS. 1997. Estructura y composición del zoobentos de ríos serranos (San Luis). Ecología Austral., 7: 28-34.

MULHOLLAND, P., C. H. DRISCOLL, J. ELWOOD, M. OSGOOD, A. PALUMBO, A. S. ROSEMOND, M. SMITH \& C. SCHOFIELD. 1992. Relationships between stream acidity and bacteria, macroinvertebrates, and fish: a comparison of north temperate and south temperate mountain streams, USA. Hydrobiologia, 239: 7-24.

RADDUM, G., A. F. JELLHEIM \& T. HESTHAGEN. 1988. Monitoring of acidification by the use of aquatic organisms. Verh. Internat. Verein. Limnol., 23: 2291-2297.

ROBACK, S. S. \& J. W. RICHARDSON. 1969. The effects of acid mine drainage on aquatic insects. Proc. Acad. Nat. Sci. Phil., 121: 81-107

ROSEMOND, A. D., S. R. REICE, J. W. ELWOOD \& P. J. MULHOLLAND. 1992. The effects of stream acidity on benthic invertebrate communities in the south-eastern United States. Freshwat. Biol., 27.193-209.

ROUSCH, J., T. SIMMONS, B. KERANS \& B. SMITH. 1997. Relative acute effects of low $\mathrm{pH}$ and high iron on the hatching and survival of the water mite (Arrenurus manubriator and the aquatic insect Chironomus riparius). Environmental Toxicology and Chemistry, 16(10): 2144-2150.

TANK, J. \& M. WINTERBOURN. 1995. Biofilm development and invertebrate colonization of wood in four New Zealand streams of contrasting $\mathrm{pH}$. Freshwat. Biol., 34: 303-315.

TRIPOLE, S., P. GONZÁLEZ, A. VALLANIA, M. GARBAGNATI \& M. MALLEA. 2006. Evaluation of the impact of acid mine drainage on the chemistry and the macrobenthos in the Carolina stream (San Luis-Argentina). Environmental Monitoring and Assessment, 114(1-3): 377-389.

TRIPOLE, E. S. \& M. del C. CORIGLIANO. 2005. Acid stress evaluation using multimetric indices in the Carolina stream (San Luis-Argentina). Acta Limnol. Bras., 17(1): 101-114.

VALLANIA, E. A., E. S. TRIPOLE y M. A. GIL. 2002. Estatus del río Grande (San Luis). Actas del V Congreso Argentino de Entomología. 18-22 marzo 2002. Buenos Aires, Argentina: 385.

VARNER, M. 2001. Variances in macroinvertebrate community structure along an acid mine drainage affected stream gradient in the central Appalachi- 
ans of West Virginia. http://www.nrac.wvu.edu/ rm493-91/fall2001/students/varner/Index.htm

VUORI, K. M. 1995. Direct and indirect effects of iron on river ecosystems. Ann. Zool. Fennici, 32: 317-329.

WARD, J. V. 1992. Other abiotic variables. In: Aquatic insect ecology.: 319-354. John Wiley \& Sons, Inc.. New York.
WINTERBOURN, M. J. \& W. F. Mc DIFFETT. 1996. Benthic faunas of streams of low pH but contrasting water chemistry in New Zealand. Hydrobiologia, 341: 101-111.

ZULLO, S. \& J. B. STAHL. 1987. Abundance, distribution and life cycles of midges (Chironomidae: Diptera) in an acid strip-mine lake in southern Illinois. The American Midland Naturalist, 119: 353-365. 